\title{
PENGARUH KEAKTIFAN MENGIKUTI EKSTRAKURIKULER PRAMUKA TERHADAP KEMANDIRIAN SISWA KELAS V SD NEGERI CIBUK LOR SEYEGAN SLEMAN TAHUN AJARAN 2017/2018
}

\author{
Devyta Restu Prihanawati \\ Nur Hidayah \\ PGSD FKIP Universitas Ahmad Dahlan \\ devyta.restu@gmail.com
}

\begin{abstract}
Independence is one of the important modalities for survival as adults. Schools are expected to teach and train children's independence through activities that can foster children's self-reliance. One of them is through extracurricular scouts. The purpose of this study is to determine the effect of activeness following extracurricular scout against the independence of students in grade V State Elementary School Cibuk Lor Seyegan Sleman Year Teaching 2017/2018 as many as 19 students.

This research is an ex post facto research and according to its method is kind of quantitative research. The population in this study were 19 students. Data collection techniques using questionnaires. Instrument validity test using product moment correlation technique with SPSS version 16.00 and reliability test using alpha cronbach technique from SPSS program version 16.00. Data analysis techniques in this study using simple linear regression analysis techniques.

The results showed that there is a positive and significant influence on the activity of extracurricular scouts on the independence of students of grade V SD Negeri Cibuk Lor Seyegan Sleman with a positive coefficient value of independence. This can be shown on the value of determinant coefficient (R2) of 0.409, tcount of 3.429 and significance value of 0.003. Because the significance value shows the number $<0,05$ then it can be concluded that the activity follows extracurricular scout have positive effect on independence.
\end{abstract}

Keywords: liveliness, extracurricular scout, independence

\begin{abstract}
ABSTRAK
Kemandirian merupakan salah satu modal penting untuk bertahan hidup ketika dewasa. Sekolah diharapkan mampu mengajarkan dan melatih kemandirian anak melalui kegiatan-kegiatan yang dapat menumbuhkembangkan sikap mandiri anak. Salah satunya yaitu melalui ekstrakurikuler pramuka. Tujuan dari penelitian ini yaitu untuk mengetahui pengaruh keaktifan mengikuti ekstrakurikuler pramuka terhadap kemandirian siswa kelas V SD Negeri Cibuk Lor Seyegan Sleman Tahun Ajaran 2017/2018 sebanyak 19 siswa.

Penelitian ini merupakan penelitian ex post facto dan menurut metodenya merupakan jenis penelitian kuantitatif. Populasi dalam penelitian ini sebanyak 19 siswa. Teknik pengumpulan data menggunakan kuesioner. Uji validitas instrument menggunakan teknik korelasi product moment dengan bantuan SPSS versi 16.00 dan uji reliabilitas menggunakan teknik alpha cronbach dari program SPSS versi 16.00. Teknik analisis data dalam penelitian ini menggunakan teknik analisis regresi linier sederhana.
\end{abstract}


Hasil penelitian menunjukkan bahwa terdapat pengaruh positif dan signifikan keaktifan mengikuti estrakurikuler pramuka terhadap kemandirian siswa kelas V SD Negeri Cibuk Lor Seyegan Sleman dengan nilai koefisien positif terhadap kemandirian. Hal ini dapat ditunjukkan pada nilai koefisien determinasinya $\left(\mathrm{R}_{2}\right)$ sebesar 0,409 , nilai thitung sebesar 3,429 dan nilai signifikansi sebesar 0,003. Karena nilai signifikansinya menunjukkan angka $<0,05$ maka dapat disimpulkan bahwa keaktifan mengikuti ekstrakurikuler pramuka berpengaruh positif terhadap kemandirian.

Kata kunci: keaktifan, ekstrakurikuler pramuka, kemandirian

\section{PENDAHULUAN}

Pendidikan merupakan upaya untuk membekali peserta didik demi kelangsungan masa depannya. Oleh sebab itu pendidikan perlu dikelola dengan baik. Penerapan konsep pendidikan di Indonesia yakni pendidikan nasional berkewajiban untuk mempersiapkan seluruh warga Indonesia untuk berperan aktif dalam semua aspek yang berguna untuk mewujudkan kehidupan masyarakat cerdas, aktif, kreatif, beradab serta mementingkan persatuan dan kesatuan. Namun, untuk meningkatkan mutu sumber daya manusia tidak hanya mengembangkan aspek intelektual saja. Akan tetapi sikap, moral, dan kepribadian juga harus dikembangkan.

Melihat fakta terjadi akhir-akhir ini di lingkungan sekolah maupun keluarga, menggambarkan terjadinya kemerosotan sikap, moral, maupun kepribadian siswa. Hal ini dibuktikan dengan kedisiplinan dan kemandirian belum tertanam di jiwa anak, dilihat dari anak tidak membuat pekerjaan rumah, anak terlambat datang ke sekolah, berpakaian tidak rapi, ketika upacara bendera masih banyak yang berbicara dengan temannya, dan kurangnya rasa hormat terhadap guru. Hal tersebut merupakan wujud dari kurangnya pendidikan karakter.

Sekolah sebagai jalur pendidikan formal merupakan salah satu pihak yang ikut bertanggung jawab terhadap pembentukan karakter peserta didik, termasuk kemandirian. Pada jalur pendidikan formal selain adanya kegiatan kurikuler sebagai kegiatan inti, tentu ada kegiatan ekstrakurikuler. Kegiatan ekstrakurikuler dilaksanakan siswa baik di dalam sekolah maupun di luar kegiatan sekolah, yang bertujuan untuk memperkaya diri dan memperluas wawasan siswa serta mendorong pembinaan nilai-nilai dan sikap siswa. Salah satu kegiatan ekstrakurikuler yang sesuai dengan program sekolah untuk menumbuh kembangkan keterampilan, kedisiplinan, kemandirian dan tanggung jawab siswa adalah ekstrakurikuler pramuka.

Tujuan kegiatan ekstrakurikuler pramuka di sekolah yakni untuk menunjang kegiatan belajar mengajar, terutama pada bidang pembentukan budi pekerti, watak dan kepribadian siswa melalui kegiatan kepramukaan sehingga siswa memiliki sikap mandiri, disiplin, tanggung jawab dan inovatif baik dalam belajar maupun kegiatan sehari-hari. Hal ini selaras dengan pendapat Melinda (2013) yang menyatakan bahwa kegiatan-kegiatan kepramukaan peserta didik selalu diarahkan untuk aktif mengikuti berbagai kegiatan kepramukaan, karena kegiatan tersebut akan mempengaruhi sikap disiplin, berani, menghargai orang lain, peduli lingkungan, cinta alam dan kemandirian. Sehingga dapat diambil kesimpulan bahwa siswa yang kurang aktif dalam mengikuti ekstrakurikuler pramuka maka berdampak pada rendahnya kedisiplinan, kemandirian, keberanian, peduli lingkungan, dan kurangnya menghargai orang lain.

Kemandirian itu sendiri memiliki arti sebagai suatu hal atau keadaan dapat berdiri sendiri tanpa bergantung pada orang lain. Seorang anak dikatakan mandiri apabila anak tersebut mampu mengambil keputusan sendiri, anak memiliki kepercayaan diri terhadap apa yang telah dikerjakan, anak mampu bertanggung jawab dan memiliki inisiatif. 
Berdasarkan hasil observasi dan wawancara pada bulan Oktober 2016 di SD Negeri Cibuk Lor Seyegan Sleman, siswa kelas V diperoleh beberapa permasalahan antara lain; Pertama, kurangnya kemandirian siswa. Hal ini tampak ketika siswa mengerjakan soal-soal seperti ulangan harian, ulangan tengah semester, maupun ulangan akhir semester. Masih terdapat separo lebih siswa melihat jawaban temannya. Ini nampak bahwa siswa belum percaya pada dirinya sendiri dan masih bergantung pada temannya. Tanggung jawab siswa rendah, hal ini tampak ketika guru sedang tugas di luar sekolah, kemudian siswa diberi tugas untuk mengerjakan soal. Namun lebih dari 50\% siswa tidak mengerjakan tugas tersebut, malah asyik bermain dengan temannya, lari-lari di dalam maupun di luar kelas.

Kedua, belum tertanamnya kedisiplinan pada diri siswa. Hal ini tampak saat bel berbunyi hampir 50\% siswa datang terlambat. Jadi, siswa datang setelah bel dibunyikan. Ada pula siswa yang sering berpura-pura ijin ke WC, padahal sebenarnya hanya tidak ingin mengikuti pelajaran. Ketika diberi tugas ada siswa yang tidak mengerjakan/mengumpulkan tugas tepat waktu.

Ketiga, kurangnya sopan santun terhadap orang yang lebih tua. Hal ini tampak ketika berbicara dengan guru masih seperti berbicara dengan teman sendiri. Ketika diberi pengertian oleh guru, tidak didengarkan justru membantah gurunya. Apabila bertemu dengan guru tidak mengucapkan salam dan tidak ada rasa hormat terhadap orang yang lebih tua.

Keempat, hampir 50\% siswa kurang aktif dalam kegiatan ekstrakurikuler kepramukaan. Hal ini tampak ketika Pembina pramuka menyampaikan materi kepramukaan, ada beberapa siswa yang tidak memperhatikan, cenderung diam dan apabila ditanya tidak bisa menjawab. Ada pula siswa yang suka membuat ramai saat upacara pembukaan maupun penutupan. Siswa yang cenderung kurang aktif dan suka membuat ramai tersebut cenderung kurang aktif dalam mengikuti ekstrakurikuler kepramukaan.

Ekstrakurikuler pramuka di SD Negeri Cibuk Lor Seyegan dilaksanakan rutin setiap hari Selasa pukul 16.00 WIB di lingkungan sekitar atau di halaman sekolah. Kegiatan ekstrakurikuler pramuka disesuaikan dengan panduan buku SKU pramuka. Pelaksanaan kegiatan ekstrakurikuler pramuka di SD Negeri Cibuk Lor Seyegan diawasi oleh Kepala Sekolah dan dikelola oleh Pembina Pramuka dengan menerapkan metode-metode Kepramukaan. Ketika pembelajaran kepramukaan siswa dibentuk regu kemudian diberi tugas secara mandiri maupun beregu. Selain latihan rutin, SD Negeri Cibuk Lor juga mengadakan perkemahan sabtu minggu maupun jambore.

\section{METODE PENELITIAN}

Penelitian ini termasuk jenis penelitian kuantitatif, yakni penelitian ini semua informasi disajikan dalam bentuk angka dan dianalisis berdasarkan analisis statistik. Sifat dari penelitian ini yaitu ex post facto, yang berarti penyelidikan secara empiris dan peneliti tidak mengendalikan variabel bebas secara langsung, karena perwujudan varibel tersebut pada dasarnya tidak ada manipulasi. Penelitian ini dimaksudkan untuk menguji hipotesis yang telah diajukan dengan cara mencari besarnya pengaruh variabel-variabel bebas terhadap variabel terikat. Penelitian ini dilaksanakan pada bulan Juli-Agustus 2017 di SD Negeri Cibuk Lor yang beralamat di Cibuk Lor, Margoluwih, Seyegan, Sleman, Yogyakarta tepatnya difokuskan pada kelas V yang berjumlah 19 siswa. Jumlah seluruh siswa kelas V SD Negeri Cibuk Seyegan Tahun Ajaran 2017/2018 yaitu 19 siswa. Hal ini berarti populasi kurang dari 100 siswa maka tidak menggunakan sampel, maka semua dijadikan sebagai objek penelitian. Sehingga penelitian ini termasuk penelitian populasi. Menurut Suharsimi (2010: 174) penelitian populasi hanya dapat dilakukan bagi populasi terhingga dan subjeknya tidak terlalu banyak, sehingga relative terjangkau untuk diteliti. 
Selain itu data yang diperoleh lebih akurat apabila semua populasi dijadikan responden. Adapun variabel dalam penelitian ini yaitu, variabel independen dalam penelitian ini yaitu ekstrakurikuler pramuka sebagai $X$, variabel dependen dalam penelitian ini yaitu kemandirian sebagai Y.

Alat untuk mengumpulkan data pada penelitian ini berupa angket/kuesioner. Angket/kuesioner yang digunakan dalam penelitian ini adalah lembar angket tertutup, karena responden tinggal memilih jawaban yang telah disediakan. Pengumpulan data dengan menggunakan angket yang disebarkan kepada responden penelitian.

Kisi-kisi instrumen penelitian keaktifan mengikuti ekstrakurikuler pramuka dikembangkan berdasarkan teori Sudjana (2014) yang dipadukan dengan Keputusan Musyawarah Nasional Gerakan Pramuka Nomor 11/Munas/2013 Pasal 3 dan Undangundang Republik Indonesia Nomor 2 tahun 2010 tentang Gerakan Pramuka pasal Jumlah item instrumen ada 20 pernyataan. Kisi-kisi instrumen penelitian kemandirian siswa dikembangkan berdasarkan teori Wiyani (2015) dan dipadukan dengan teori Yamin dalam Yuyun (2014).

Pada penelitian ini proses uji validasi dilakukan dalam 2 tahap yaitu validasi isi dan korelasi butir soal. Validasi isi dilakukan dengan menggunakan pendapat dari ahli (judgment experts) yaitu ahli di bidang ekstrakurikuler pramuka, kemandirian siswa. Dalam hal ini setelah instrumen dikonstruksi mengenai aspek-aspek yang akan diukur berlandaskan teori tertentu, kemudian dikonsultasikan dengan ahli tersebut. Apabila ahli sepakat bahwa butir soal tersebut relevan, maka butir soal tersebut dinyatakan layak untuk mendukung validasi isi.

Langkah selanjutnya yaitu korelasi butir soal dengan perhitungan statistik. Untuk menguji validitas setiap butir digunakan analisis item, yakni skor-skor tiap butir soal dikorelasikan dengan skor total. Oleh sebab itu digunakan teknik korelasi product moment dengan pengolahan data menggunakan SPSS versi 16.00. Syarat minimum bahwa penelitian dianggap valid, apabila $r=0,3$. Jadi apabila terjadi korelasi korelasi antara butir soal dengan skor total $<0,3$, maka instrumen tersebut dinyatakan tidak valid sehingga tidak dapat digunakan untuk mengambil data penelitian. Pengujian validitas pada penelitian ini dilakukan pada 20 butir pernyataan mengenai ekstrakurikuler kepramukaan dan 20 butir pernyataan kemandirian. Validitas isi kuesioner dikonsultasikan dengan dosen ahli dan didasarkan pada kisi-kisi. Pada penelitian ini untuk menguji reabilitas instrumen, menggunakan teknik alpha cronbach dari program SPSS 16. Menurut Siregar (2012: 175) kriteria suatu instrumen penelitian dikatakan reliabel dengan menggunakan teknik ini, bila koefisien reliabilitas $(\mathrm{r} 11)>0,60$.

Teknik analisis data menggunakan uji parameter dan uji hipotesis, uji parameter terdiri dari uji normalitas yang digunakan untuk menguji normal atau tidaknya distribusi nilai residual yang dihasilkan dari regresi. Untuk menguji normalitas data digunakan uji statistik menggunakan chi kuadrat (x2) dengan bantuan SPSS 16. Data dapat dikatakan terdistribusi normal apabila $\mathrm{p}>0,05$. Kemudian, uji linieritas linieritas digunakan untuk mengetahui linier atau tidaknya hubungan dua variabel. Pada pengujian linieritas ini menggunakan bantuan program SPSS versi 16.00. Hubungan dua variabel dikatakan linier apabila nilai signifikansinya $<0,05$. Terdapat pula uji homosedastisitas yang digunakan untuk mengetahui apakah dalam analisis regresi terjadi ketidaksamaan variansi residu dari suatu pengamatan ke pengamatan lain. Regresi yang baik hasilnya tidak terjadi homosedastisitas. Selain itu uji homosedastisitas juga bisa menggunakan uji Rho Spearman. Dalam uji ini yang perlu ditafsirkan bagian koefisien antara variabel independen dengan absolut residu. Jika nilai sig < 0,05 maka tidak terjadi homosedastisitas, jikasebaliknya maka terjadi homosedastisitas. Jenis data yang diperoleh pada penelitian ini yaitu data interval karena 
memiliki bentuk skala 1 sampai 4 . Uji hipotesis pada penelitian ini bertujuan untuk membuktikan kebenaran dari hipotesis yang sudah dirumuskan. Uji koefisien Determinasi (R2), merupakan ukuran penting dalam analisis regresi, karena dapat mengukur jarak garis regresi yang terestimasi dengan sesungguhnya. Sehingga persamaan garis regresi merujuk pada rumus $\mathrm{Y}=\mathrm{a}+\mathrm{bX}$.

\section{HASIL DAN PEMBAHASAN}

\section{A. Hasil Penelitian}

\section{Deskripsi Data}

Data penelitian diperoleh dari siswa kelas V SD Cibuk Lor Seyegan Sleman yang berupa data hasil angket dari variabel bebas yaitu keaktifan mengikuti ekstrakurikuler pramuka (x) terhadap variabel terikat yaitu kemandirian (y). Penelitian ini termasuk penelitian populasi, karena objek dalam penelitian ini kurang dari 100 siswa. Sehingga semua dijadikan sebagai objek penelitian. Pada bagian ini akan disajikan deskripsi data dari tiap-tiap variabel meliputi skor tertinggi, skor terendah, mean (M), dan standar deviasi (SD). Pengolahan data dilakukan dengan bantuan SPSS Versi 16.00.

a. Variabel Kemandirian

Data variabel Kemandirian diperoleh angket yang terdiri atas 18 butir pernyataan. Skor yang diberikan maksimal 4 dan minimal 1, sehingga diperoleh skor tertinggi ideal 72 dan skor terendah ideal 18. Berdasarkan data penelitian, variabel kemandirian memiliki skor tertinggi sebesar 72, skor terendah sebesar 51 , mean sebesar 60,74 dan standar deviasi 7,63. Jumlah kelas interval ditentukan dengan rumus $\mathrm{K}=1+3,3 \log 18$, hasilnya adalah 5,14 untuk mempermudah perhitungan maka dibulatkan ke bawah menjadi 5 . Rentang data $72-43=29$. Sedangkan panjang kelas didapat dari rentang kelas dibagi dengan jumlah kelas yaitu $29 / 5=5,8$ dibulatkan menjadi 6 . Berikut disajikan diagram batang distribusi frekuensi variabel kemandirian.

Gambar 1. Diagram Distribusi Frekuensi Variabel Kemandirian

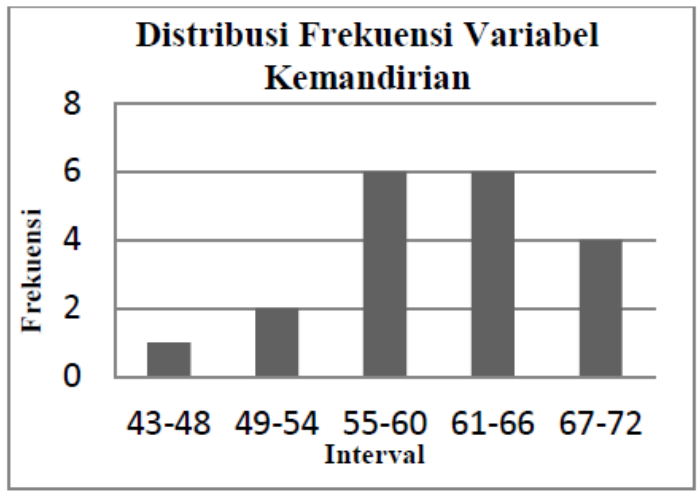

Berdasarkan diagram batang di atas dapat dilihat bahwa skor kemandirian paling tinggi berada di interval 55-60 dan interval 61-66 yaitu sebanyak 6 responden $(31,6 \%)$ pada masing-masing interval. Selanjutnya, kemandirian digolongkan ke dalam kriteria skor ideal 4 kategori yaitu sangat tinggi, tinggi, rendah dan sangat rendah. Berikut ditampilkan kecenderungan variabel kemandirian. 
Tabel 1. Kategori Kecenderungan Kemandirian

\begin{tabular}{|c|c|c|c|c|}
\hline No & Kelas & Frekuensi & Prosentase & Kategori \\
\hline 1 & $X>57$ & 12 & $63 \%$ & Sangat tinggi \\
\hline 2 & $45<X \leq 57$ & 6 & $32 \%$ & Tinggi \\
\hline 3 & $33<X \leq 45$ & 1 & $5 \%$ & Rendah \\
\hline$T$ & $X \leq 33$ & 0 & $0 \%$ & Sangat Rendal \\
\hline & Jumlah & 19 & $100 \%$ & \\
\hline
\end{tabular}
berikut.

Kecenderungan variabel kemandirian juga dapat dilihat dalam lingkaran

Gambar 2. Diagram Lingkaran Kecenderungan Variabel Kemandirian

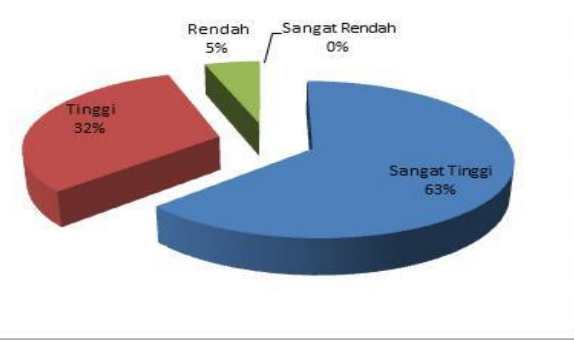

Berdasarkan hasil analisis data yang telah dilakukan, menunjukkan bahwa kemandirian berdasarkan tanggapan responden termasuk dalam kategori sangat tinggi dengan frekuensi sebanyak 12 responden atau 63\%.

b. Variabel Keaktifan Mengikuti Ekstrakurikuler Pramuka

Data variabel Keaktifan Mengikuti Ekstrakurikuler Pramuka diperoleh dari angket yang terdiri dari 19 pernyataan. Skor yang diberikan maksimal 4 dan minimal 1, sehingga diperoleh skor tertinggi ideal 76 dan skor terendah ideal adalah 19. Berdasarkan data penelitian, variabel keaktifan mengikuti ekstrakurikuler pramuka memiliki skor tertinggi sebesar 76, skor terendah sebesar 52, mean sebesar 60.79 dan standar deviasi sebesar 7,009. Jumlah kelas interval ditentukan dengan rumus $\mathrm{K}=1+3,3 \log 19$, hasilnya adalah 5,21 untuk mempermudah perhitungan maka dibulatkan kebawah menjadi 5. Rentang data 76-48 $=28$. Sedangkan panjang kelas didapat dari rentang kelas dibagi dengan jumlah kelas yaitu $28 / 5=5,6$ dibulatkan menjadi 6 . Berikut disajikan diagram batang distribusi frekuensi variabel keaktifan mengikuti ekstrakurikuler pramuka.

Gambar 3. Diagram Distribusi Frekuensi Variabel Keaktifan

Mengikuti Ekstrakurikuler Pramuka

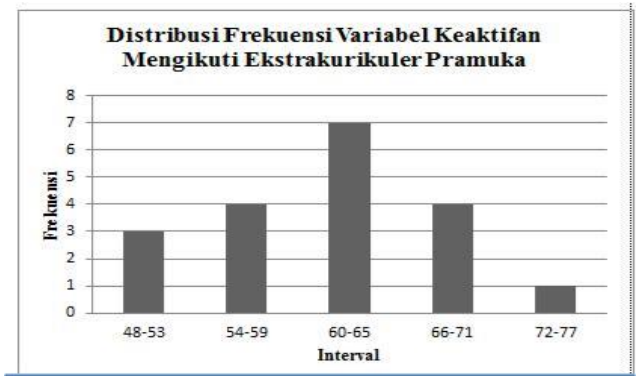

Berdasarkan diagram batang di atas dapat dilihat bahwa skor keaktifan mengikuti ekstrakurikuler pramuka paling tinggi berada di interval 60-65 yaitu sebanyak 7 responden $(36,9 \%)$. Selanjutnya, keaktifan mengikuti ekstrakurikuler pramuka digolongkan ke dalam kriteria skor ideal 4 kategori 
yaitu sangat tinggi, tinggi, rendah dan sangat rendah. Berikut ditampilkan kecenderungan variabel keaktifan mengikuti ekstrakurikuler pramuka.

Tabel 2. Kategori Kecenderungan Keaktifan Mengikuti Ekstrakurikuler Pramuka

\begin{tabular}{|l|l|c|c|c|}
\hline No & \multicolumn{1}{|c|}{ Kelas } & Frekuensi & Prosentase & Kategori \\
\hline 1 & $\mathrm{X}>61,75$ & 9 & $47 \%$ & Sangat tinggi \\
\hline 2 & $47,5<\mathrm{X} \leq 61,75$ & 10 & $53 \%$ & Tinggi \\
\hline 3 & $33,25<\mathrm{X} \leq 47,5$ & 0 & $0 \%$ & Rendah \\
\hline 4 & $\mathrm{X} \leq 33,25$ & 0 & $0 \%$ & Sangat Rendah \\
\hline \multicolumn{2}{|c|}{ Jumlah } & 19 & $100 \%$ & \\
\hline
\end{tabular}

Kecenderungan variabel keaktifan mengikuti ekstrakurikuler pramuka juga dapat dilihat dalam lingkaran berikut.

Gambar 4. Diagram Kecenderungan Keaktifan Mengikuti Ekstrakurikuler Pramuka

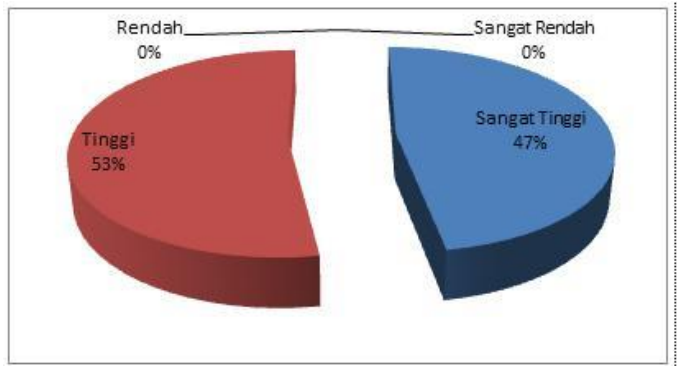

Berdasarkan hasil analisis data yang telah dilakukan, menunjukkan bahwa keaktifan mengikuti ekstrakurikuler pramuka berdasarkan tanggapan responden termasuk dalam kategori tinggi dengan frekuensi sebanyak 10 responden atau $53 \%$.

2. Pengujian Prasyarat Analisis

a. Uji Normalitas

Uji normalitas digunakan untuk mengathui data dari masing-masing terdistribusi normal atau tidak. Rumus yang digunakan adalah rumus Kolmogrow Smirnov, untuk mengetahui apakah distribusi frekuensi masingmasing variabel normal atau tidak dapat dilihat dari nilai Asymp. Sig. Jika nilai Asymp. Sig. (2-tailed) $<0,05$ maka data tersebut tidak berdistribusi normal, namun sebaliknya jika nilai Asymp. Sig. (2-tailed) $\geq 0,05$ maka data berdistribusi normal. Dengan bantuan SPSS Versi 16.00 hasil uji normalitas ditunjukkan tabel berikut.

Tabel 3. Ringkasan Hasil Uji Normalitas

\begin{tabular}{|c|l|c|c|c|}
\hline No & \multicolumn{1}{|c|}{ Nama Variabel } & $\begin{array}{c}\text { Kolmogorov- } \\
\text { Smirnov Z }\end{array}$ & $\begin{array}{c}\text { Nilai } \\
\text { Asymp } \\
\text { Sig }\end{array}$ & $\begin{array}{c}\text { Hasil } \\
\text { Pengujian }\end{array}$ \\
\hline 1. & $\begin{array}{l}\text { Keaktifan Mengikuti } \\
\text { Ekstrakurikuler } \\
\text { Pramuka }\end{array}$ & 0.737 & 0.649 & Normal \\
\hline 2. & Kemandirian & 0.623 & 0.833 & Normal \\
\hline
\end{tabular}

Berdasarkan hasil pengujian yang ditunjukkan pada tabel di atas nilai Asymp. Sig (2-tailed) untuk variabel keaktifan mengikuti ekstrakurikuler pramuka adalah $0.649 \geq 0,05$ dan variabel kemandirian menunjukkan Asymp. Sig (2-tailed) $0.833 \geq 0,05$, sehingga dapat disimpulkan data variabel keaktifan mengikuti ekstrakurikuler pramuka dan kemandirian terdistribusi normal.

b. Uji Linieritas

Uji Linieritas digunakan untuk mengetahui hubungan antar variabel bebas dan variabel terikat bersifat linier atau tidak. Kriterianya, jika harga sig tersebut $<0,05$ maka hubungannya tidak linier, sedangkan jika nilai sig $\geq 0,05$ maka 
hubungannya bersifat linier. Setelah dilakukan perhitungan dengan bantuan SPSS versi 16.00, hasil uji linieritas dapat ditunjukkan tabel berikut:

Tabel 4. Ringkasan Hasil Uji Linieritas

c. Uji Homosedastisitas

\begin{tabular}{|c|c|c|c|c|}
\hline \multicolumn{2}{|c|}{ Variabel } & \multirow{2}{*}{ S } & Sig & Kesimpulan \\
\hline \multicolumn{1}{|c|}{ Bebas } & Terikat & & \\
\hline $\begin{array}{l}\text { Keaktifan Mengikuti } \\
\text { Ekstrakurikuler } \\
\text { Dramuka }\end{array}$ & Kemandirian & 0.361 & 0.925 & Limier \\
\hline
\end{tabular}

Uji Hhomosedastisitas digunakan untuk mengetahui kesamaan varians error untuk setiap nilai X. Ada tidaknya homosedastisitas dapat dilihat dari pola grafik antara nilai prediksi variabel terikat dengan residualnya. untuk memperkuat pengujian homosedatisitas digunakan juga uji Rho Spearman. Dalam uji ini perlu ditafsirkan hanyalah bagian koefisien korelasi Rho Spearman antara variabel independen dengan absolut residu. Jika nilai sig < 0,05 maka tidak terjadi homosedatisitas, jika sebaliknya maka terjadi homosedastisitas.Hasil uji homosedastisitas dengan bantuan SPSS 16.00 adalah sebagai berikut:

Tabel 8. Hasil Uji Homosedastisitas

\begin{tabular}{|l|c|c|c|}
\hline \multicolumn{1}{|c|}{ Variabel } & $\begin{array}{c}\text { Spearman's } \\
\text { rho }\end{array}$ & Sig. & Kesimpulan \\
\hline $\begin{array}{l}\text { Keaktifan } \\
\text { Mengikuti }\end{array}$ & 0.144 & 0.556 & Homosedastisitas \\
$\begin{array}{l}\text { Ekstrakurikuler } \\
\text { Pramuka }\end{array}$ & & & \\
\hline
\end{tabular}

Berdasarkan tabel di atas nilai signifikansi (Sig.) > 0,05 maka dapat disimpulkan analisis regresi tersebut memenuhi syarat homosedastisitas. Dari tabel di atas nilai signifikansi (Sig.) > 0,05 maka dapat disimpulkan analisis regresi tersebut memenuhi syarat homosedastisitas.

3. Uji Hipotesis

a. Uji Koefisien Determinasi (R2)

Koefisien determinasi (R2) digunakan untuk menunjukkan seberapa besar persentase variabel bebas (keaktifan mengikuti ekstrakurikuler pramuka) secara bersama-sama menerangkan variansi variabel terikat (kemandirian). Hasil pengujian regresi menunjukkan bahwa koefisien determinasi (R2) sebesar 0.409 atau $40,9 \%$. Nilai tersebut menunjukkan bahwa $40,9 \%$ kemandirian dipengaruhi oleh keaktifan mengikuti ekstrakurikuler pramuka. Sedangkan sisanya yaitu 59,1\% dipengaruhi oleh variabel yang tidak diteliti dalam penelitian ini.

b. Persamaan Garis Regresi

Analisis yang digunakan dalam penelitian ini adalah analisis regresi sederhana. Berikut rangkuman hasil analisis regresi sederhana.

Tabel 9. Rangkuman Hasil Analisis Regresi Sederhana

\begin{tabular}{|l|c|c|c|c|}
\hline \multicolumn{1}{|c|}{ Model } & $\begin{array}{c}\text { Koefisien } \\
\text { Regresi (B) }\end{array}$ & thitum & Sig. & Kesimpulan \\
\hline $\begin{array}{l}\text { Keaktifan Mengikuti } \\
\text { Ekstrakurikuler } \\
\text { Pramuka (X) }\end{array}$ & 0,688 & 3,429 & 0,003 & Signifikan \\
\hline Konstanta & 18,926 & \\
\hline $\mathrm{R}$ & 0,639 & \\
\hline $\mathrm{R}^{2}$ & 0,409 & \\
\hline F hitung & 11,757 \\
\hline Sig & 0,003 \\
\hline
\end{tabular}

Berdasarkan hasil analisis regresi tersebut dapat diketahui persamaan garis regresi sebagai berikut: $\mathrm{Y}=18,926+0,688 \mathrm{X}$ 


\section{B. Pembahasan}

Berdasarkan hasil penelitian dapat disimpulkan bahwa keaktifan mengikuti ekstrakurikuler pramuka berpengaruh positif terhadap kemandirian. Hal ini dapat ditunjukkan pada nilai koefisien determinasinya (R2) sebesar 0,409, nilai thitung sebesar 3,429 dan nilai signifikansi sebesar 0,003 . Karena nilai signifikansinya menunjukkan angka $<0,05$ maka dapat disimpulkan bahwa keaktifan mengikuti ekstrakurikuler pramuka berpengaruh positif terhadap kemandirian. Ini berarti semakin tinggi keaktifan mengikuti ekstrakurikuler pramuka maka akan semakin tinggi kemandirian siswa. Namun hal ini berlaku sebaliknya apabila keaktifan mengikuti ekstrakurikuler pramuka rendah makan akan semakin rendah kemandirian siswa. Hal tersebut telah sesuai dengan teori yang diungkapkan oleh pendapat Melinda (2013) yang menyatakan bahwa dalam kegiatankegiatan kepramukaan peserta didik selalu diarahkan untuk aktif mengikuti berbagai kegiatan kepramukaan, karena kegiatan tersebut akan mempengaruhi sikap disiplin, berani, menghargai orang lain, peduli lingkungan, cinta alam dan kemandirian. Selain itu, hal tersebut telah sesuai dengan proses pendidikan kepramukaan yang membentuk peserta didik agar berjiwa merdeka, disiplin dan mandiri dalam hubungan timbal balik antar manusia (Team DAP, 2012). Hal ini juga sejalan dengan Keputusan Musyawarah Nasional Gerakan Pramuka Nomor 11/Munas/2013 Pasal 3 yang menyebutkan bahwa Gerakan Pramuka bertujuan untuk membentuk setiap pramuka:

a. Memiliki kepribadian yang beriman, bertakwa, berakhlak mulia, berjiwa patriotik, taat hukum, disiplin, menjunjung tinggi nilai-nilai luhur bangsa, bekecakapan hidup, sehat jasmani, dan rohani;

b. Menjadi warga Negara yang berjiwa Pancasila, setia, dan patuh kepada Negara Kesatuan Republik Indonesia serta menjadi masyarakat yang baik dan berguna, yang dapat membangun dirinya sendiri secara mandirisertabersama-sama bertanggungjawab atas pembangunan bangsa dan Negara, memiliki kepedulian terhadap sesama hidup dan alam lingkungan.

Selanjutnya, pada koefisien determinasi (R2) yang menunjukkan nilai 0,409 dapat diketahui kontribusi/sumbangan keaktifan mengikuti ekstrakurikuler pramuka terhadap kemandirian sebesar 40,9\% dan sisanya $59,1 \%$ dipengaruhi oleh variabel lain yang tidak diteliti pada penelitian ini.

\section{KESIMPULAN}

Berdasarkan data yang diperoleh dari hasil analisis yang dilakukan, maka dapat ditarik kesimpulan bahwa keaktifan mengikuti ekstrakulikuler pramuka dapat mempengaruhi kemandirian siswa secara positif dan signifikan. Hal ini, dapat ditunjukkan dengan nilai thitung sebesar 3,429, nilai koefisien dterminasi (R2) sebesar 0,409 dan nilai signifikansinnya sebesar 0,003 . Karena nilai signifikansinya menunjukkan angka $<0,05$ maka dapat disimpulkan bahwa keaktifan mengikuti ekstrakulikuler pramuka berpengaruh positif terhadap kemandirian siswa. Sumbangan efektif kedua variabel sebesar 40,9\%, sedangkan siswanya $59,1 \%$ dipengaruhi oleh variabel lain yang tidak diteliti pada penelitian ini.

\section{DAFTAR PUSTAKA}

Arikunto, Suharsimi. 2010. Prosedur Penelitian Suatu Pendekatan Praktik. Jakarta: PT Rineka Cipta.

Melinda, Elly Sri. 2013. Pendidikan Kepramukaan: Implementasi Pendidikan Khusus.Jakarta: PT Luxima Metro Media. 
Sudjana, Nana. 2014. Penilaian Hasil Proses Belajar Mengajar. Bandung: PT Remaja Rosdakarya.

Sugiyono. 2007. Statistika Untuk Penelitian Pendidikan Pendekatan Kuantitatif, Kualitatif, dan $R \& D$. Bandung: Alafabeta.

Team DAP. 2012. Buku Pintar Pramuka. Jakarta: DAP Jakarta. 